\title{
街路景観の印象評価予測に関する研究
}

\author{
○中 和美, 佐藤 仁人（東京電力. 電力技術研究所）
}

\section{A study on a Prediction of the Impression of Streetscapes}

Kazumi Nakayama, Masato Sato (Tokyo Electric Power Company, Power Engineering R \& D Center)

\section{1、はじめに}

感覚評価を用いて景観設計を行う場合、単にある 景觀に対する印象を評価するのみでなく、街路の状 態から印象評価值が予測できるように、心理的要因 と視覚的要素とを結びつけることが大切である。筆 者ら1は、市街地の街路景観の調和感につながる心 理的要因と街路構成要素を明らかにするとともに、 これら相互の関連づけを試みた。本論文は、その結 果をもとに、Neural Networkを用いて街路構成要素 から感覚的な調和の度合いを予測することを目的と 古る。

\section{2. 街路景観の評価実験}

まず、収集した104枚の様々な市街地の街路の写 真1)から、街路の分類が異なること、3 棟以上が並 んでいることを条件に、5街路の写真をスキャナで ハイビジョン画像に取り込んだ。これらの画像に、 9 種類の街路構成要素を 1 要素ずつ変化してみられ るように、フォトモンタージュにより画像を操作し た。表1に、画像 $(A \sim E)$ と、操作の種類 $(1$ 9) の関係を示す。街路によっては、要素の適用が 困難なものもあるため、原画像を含めて41画像を評 価刘象刺激とした。画像の例を写真 1 に示寸。実験
は臨場感をもたせるために120インチのハイビジョ ンモニターを用いて行い、画像の例を 2 パターン呈 示した後、41の画像をランダムに呈示した。評価手 法はその画像が映し出す街路全体の調和感を問う、

1.非常に調和していない、2.調和していない、3.やや調 和していない、4.どちらともいえない、5.やや調和して いる、6.調和している、7.非常に娚和しているの7段階 評定であった。被験者は建築デザイン関係者20名で あった。

\section{3. 評価寒験の結果}

調和感の被験者平均值の結果、原画像では街路 $B$ (4.35)、 $\mathrm{C}(4.10) 、 \mathrm{E}(3.95) 、 \mathrm{D}(3.60) 、 \mathrm{~A}(3.25)$ の)順 に評価が高く、やや調和していない〜やや調和して いるの間に位置する。図1に、街路ごとに原画像と 街路構成要素を適用した画像との調和感評価の差を 示す。街路AＣＤ徍路構成要素の適用によって評 価に差が現れやすく、街路BEでは効果が現れにく

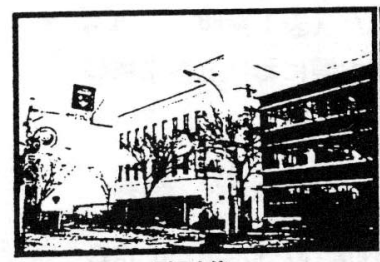

C 原画像

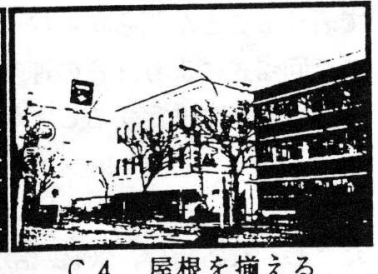

C 4 屋根を揃える
写真 1 刺激の任

表 1 街路盽成要素操作内容と画像人の道用

\begin{tabular}{|c|c|c|c|c|c|c|c|c|c|c|c|c|c|c|c|c|c|c|c|c|c|c|c|c|}
\hline \multicolumn{2}{|c|}{ 操作No } & \multicolumn{3}{|c|}{1} & \multicolumn{2}{|c|}{2} & \multicolumn{2}{|c|}{3} & \multicolumn{2}{|c|}{4} & \multicolumn{2}{|c|}{5} & \multicolumn{2}{|c|}{6} & \multicolumn{3}{|c|}{7} & \multicolumn{2}{|c|}{8} & \multicolumn{3}{|c|}{9} & \multicolumn{2}{|c|}{ 洼哭の特数 } \\
\hline \multirow{2}{*}{\multicolumn{2}{|c|}{$\begin{array}{l}\text { 棈 } \\
\text { 成 } \\
\text { 要 } \\
\text { 意 }\end{array}$}} & \multicolumn{3}{|c|}{ 街器澍 } & \multicolumn{2}{|c|}{ 建物の愊 } & \multicolumn{2}{|c|}{ テザイン } & \multicolumn{2}{|c|}{ 屋根 } & \multicolumn{2}{|c|}{ 高さ } & \multicolumn{2}{|c|}{ 忩の形 } & \multicolumn{3}{|c|}{ 看板 } & \multicolumn{2}{|c|}{ 世上螘 } & \multicolumn{3}{|c|}{ 龟總雷柆 } & \multirow[b]{2}{*}{ 車两の, } & \multirow[b]{2}{*}{$\begin{array}{c}\text { 建物高さ } \\
\text { と道幅 }\end{array}$} \\
\hline & & $\begin{array}{l} \pm \\
1\end{array}$ & $\begin{array}{l}\text { के } \\
\eta\end{array}$ & 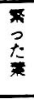 & $\begin{array}{l}\text { 型 } \\
\vdots \\
2 \\
\vdots\end{array}$ & $\begin{array}{l}\text { m } \\
\vdots\end{array}$ & 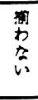 & $\begin{array}{l}\text {; } \\
\text { j }\end{array}$ & 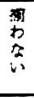 & j & 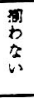 & ता & 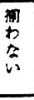 & j & $\begin{array}{l}\text { 多 } \\
w^{2}\end{array}$ & $\begin{array}{l}\text { 少 } \\
2 \\
\text { 小 }\end{array}$ & L & 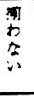 & $\begin{array}{l}3 \\
i\end{array}$ & $\begin{array}{l}3 \\
w\end{array}$ & $\begin{array}{l}\text { 少 } \\
2 \\
2\end{array}$ & $\begin{array}{l}2 \\
L\end{array}$ & & \\
\hline \multirow{3}{*}{ 挂 } & A & & 0 & 인 & 0 & - & 0 & ㄴ & 0 & 을 & 0 & 0 & 0 & - & 0 & & 0 & 0 & - & 0 & 0 & & 多i & 汪洒こ \\
\hline & 8 & & 0 & 0 & 0 & - & 0 & 0 & 0 & - & 0 & - & 0 & 9 & & 0 & 0 & 0 & 0 & - & & 0 & 少究以 & 建物が大 \\
\hline & C & & 0 & 0 & C & 0 & 0 & - & 0 & 단 & 0 & 0 & 0 & 0 & 0 & & - & 0 & 0 & - & & 0 & $\neq 2$ & 建物が小 \\
\hline \multirow[t]{2}{*}{ 路 } & 0 & 0 & & 0 & 0 & 9 & 0 & - & 2 & - & 0 & 0 & 0 & 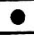 & 0 & & 인 & 0 & 0 & ㄴ & 0 & & 少2い & 建物放大 \\
\hline & $E$ & 0 & & 0 & 0 & - & 0 & - & 0 & 0 & 0 & - & 0 & 0 & 0 & & 9 & 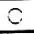 & - & - & 0 & & 少和 & 汪级可し \\
\hline
\end{tabular}


い。街路構成要素に関しては、街路樹を葉が繁った 状態にすること、建物の高さや仕上げを揃えるこ と、看板をなくすことが、常に調和感の評価を高く し、電線電柱を付加すると調和感を低める。建物の デザインや空の形を揃えると、街路によっては調和 感の評価を低下きせる場合もみられる。

\section{Neural Networkによる印集評価予测}

街路構成要素の状態から調和感の評定平均値を予 測させるシステムをNeural Network（階層構造Neural Networkモデル、Back Propagation法) を用いて 作成した。予测に用いる変数は、表 1 に示す 9 種類 の操作項目に街路の特徽を示す 2 分類を加えた11変 数とし、このうち看板・車両の量・道幅は量的変 数、その他はカテゴリー変数とした。予測する变数 は、調和感の評定平均値である。41画像の評価結果 のばらつきを考虑して30画像と11画像とに分け、 システム作成では30画像分の情報を学習用とし、 11画像分をシステム検証用とした。試行錯誤の結 果、中間層は 2 層（1層目35unit、2層目15unit）、 学習回数209回で、学習および検証それぞれのデー タとシステム出力結果の相関が最も高い値を得た。 完成したシステムの精度を確認するために、学習 データの再現と検証用データの予測を行った（図 2、3）。学習デー夕の相関係数は0.919で、非常 に高い精度で再現できた。検証用デー夕を用いた予 測でも、相関係数は0.860あり、学習に用いなかっ た画像についても高い精度で予測できた。

次に、街路構成要素に着目し、感度解析により各 要素が評価に与える影響度を求めた（図 4 ）。調和 感の評価に最も大きく影響するのは電線電柱であ る。また、建物の高兰等建物そのものの要素を揃え ることが街路の調和感を高める。この傾向は、図 1 の傾向と概ね一致している。

\section{5.まとめ}

街路構成要素の状態から街路の調和感を予測きせ るシステムをNeural Networkを用いて作成した結 果、デー夕の再現・予測精度とも高いシステムを作 成することができた。
今後は要素間の複合効果の影響、構成要素の定量 化を考虑しながらNeural Networkによる印象評価予 測システムの最適化を試みる予定である。

【䝰辞】

本論文をまとめるにあたりこ助力いただいた大成建設の大山能永 氏、東重設計の松島学氏および河村知之氏に感即の意を表します。

【引用文熾】

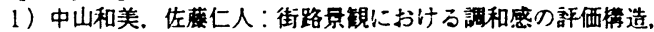
人間工学, 第30巻特別号, 1994.

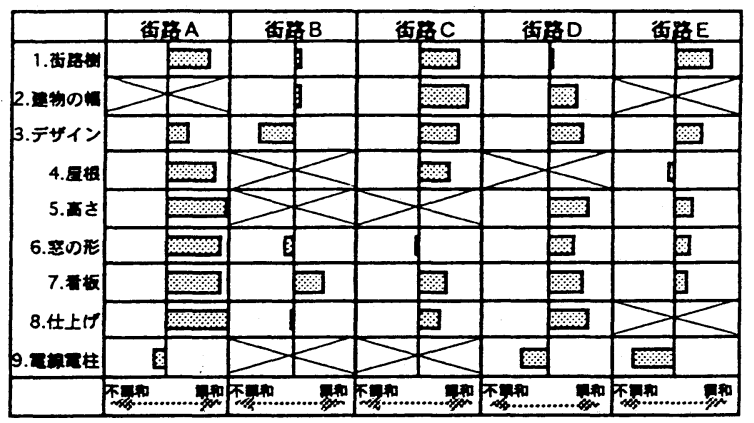

图 1 街路椿成要素道用による䚴和感評価の差

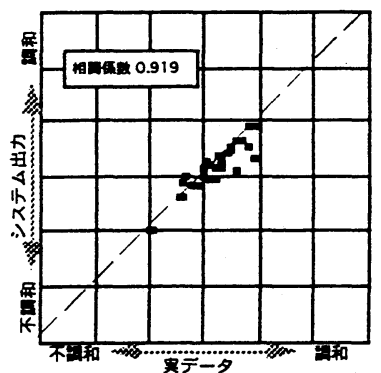

图 2 学習データの再現

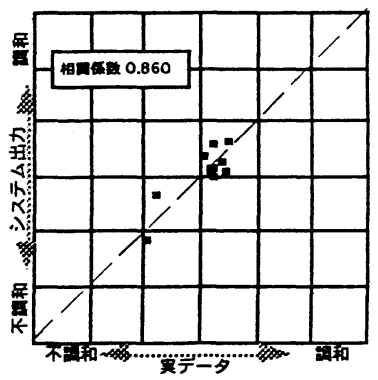

図 3 榆証用データの予测

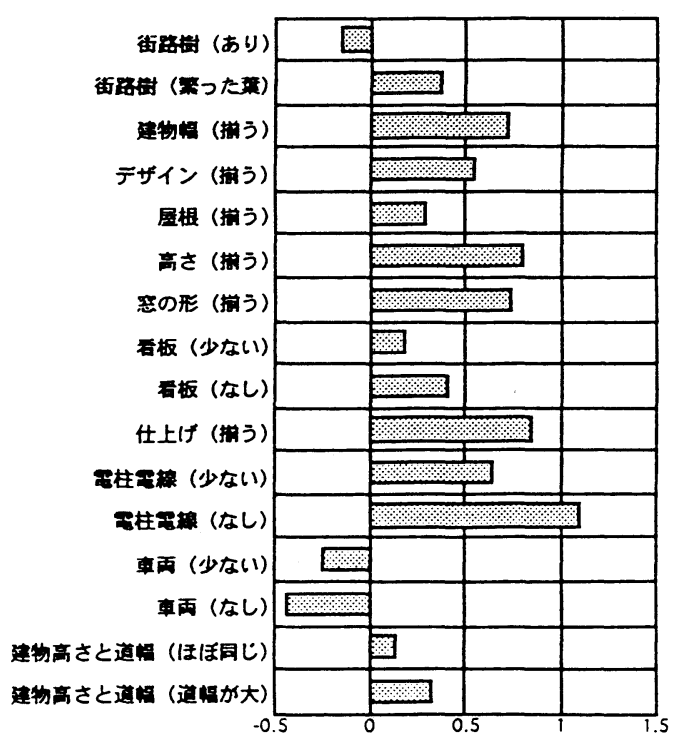

図 4 街路棈成要素の効果 